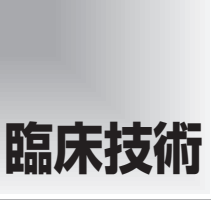

論文受付 2020 年 8 月 19 日

論文受理

2021 年 3 月 4 日

Code No. 761

\section{拡散強調画像におけるファントムスタディのための 使用材料の提案}

\author{
上田未来 ${ }^{1}$ 高津安男 $^{2,3}$ 朝原正喜 $^{2}$
}

\author{
1 徳島文理大学保健福祉学部診療放射線学科 (現 山口県立総合医療センター中央放射線部) \\ 2 徳島文理大学保健福祉学部診療放射線学科 \\ 3 徳島文理大学大学院工学研究科システム制御工学専攻
}

\section{緒 言}

今日の磁気共鳴検査 (magnetic resonance imaging: MRI)において, 拡散強調画像 (diffusion weighted image: DWI) は欠かせないものとなっている. 特に救急 の現場における急性期脳梗塞の診断に有用とされてい る1,2)。また, がん検索の全身応用など, 拡散強調画像 の用途は幅広い3).更に, DWIによって得られる, 見か けの拡散係数 (apparent diffusion coefficient: ADC) は $\mathrm{T}_{2}$ の影響 $\left(\mathrm{T}_{2}\right.$ shine-through)を排除するために有用で
あり ${ }^{4)}$ それは温度によって変化することが知られて いる5).

シーケンスパラメータの最適化などによる画質の変 化を確認する場合，臨床で使用する前段階として客観 的に評価する手段にファントムが使用される6)。 た, ファントムは温度などの物理変化の測定や定量化 にも用いられている。過去の報告では，田村らはゼラ チンとスクロースおよび塩化マンガン ${ }^{7)}$, Takatsu ら はデキストリン ${ }^{8)}$, Gatidis らはポリエチレングリコール

\title{
A Proposal for the Optimal Material for Evaluating Diffusion-weighted Image by Using Solid Phantom
}

\author{
Mirai Ueda, ${ }^{1 *}$ Yasuo Takatsu, ${ }^{2,3}$ and Masaki Asahara ${ }^{2}$ \\ ${ }^{1}$ Department of Radiological Technology, Faculty of Health and Welfare, Tokushima Bunri University \\ (Current address: Department of Central Radiology, Yamaguchi Prefectural Grand Medical Center) \\ ${ }^{2}$ Department of Radiological Technology, Faculty of Health and Welfare, Tokushima Bunri University \\ ${ }^{3}$ Department of System Control Engineering, Graduate School of Engineering, Tokushima Bunri University
}

Received August 19, 2020; Revision accepted March 4, 2021

Code No. 761

\section{Summary}

Recently, diffusion-weighted imaging (DWI) has become essential for diagnosing acute cerebral infractions and detecting lesions via magnetic resonance imaging (MRI). Investigations using phantoms have been performed to evaluate the optimizing parameters before clinical practice. However, there have been no studies on extracting appropriate phantom materials. It is known that the apparent diffusion coefficient (ADC) changes with temperature. To extract optimal materials from polyethylene glycol, sucrose, and dextrin in previous studies, evaluations were performed using ADC with temperature change and signal-to-noise ratio (SNR). Results of comparison with difference between true and measured values depend on the Stokes-Einstein formula for ADC change with temperature change; the highest value was obtained for polyethylene glycol. In the SNR measurement, when the temperature increased, the rate of change of ADC decreased. Polyethylene glycol showed the highest value. According to these results, it can be concluded that polyethylene glycol can be extracted when nearest to true value and when there is a high SNR, thus making polyethylene glycol the most suitable material for diffusion-weighted image phantoms.

Key words: magnetic resonance imaging (MRI), diffusion-weighted imaging (DWI), phantom, apparent diffusion coefficient (ADC), temperature

*Corresponding author 
Table $T_{1}$ and $T_{2}$ values, and ADC of solid phantom measured by the predefined region of interest

\begin{tabular}{lcccc}
\hline \hline & Concentration (wt\%) & $\mathrm{T}_{1}$ value (ms) & $\mathrm{T}_{2}$ value (ms) & $\begin{array}{c}\text { Apparent diffusion coefficient (ADC) } \\
\left(\times 10^{-3} \mathrm{~mm}^{2} / \mathrm{s}\right)\end{array}$ \\
\hline Polyethylene glycol (PEG) & 20 & 1030 & 250 & 1.00 \\
Dextrin (DEX) & 30 & 662 & 39 & 1.12 \\
Sucrose (SC) & 30 & 914 & 57 & 1.11 \\
\hline
\end{tabular}

とガドブトロールを用いた拡散強調画像用ファント ム 累をそれぞれ作製し，使用した研究について報告し ている。このようにファントムの作製や性能評価に関 してさまざまな研究が行われているものの ${ }^{6-9)}$, これ らのファントムを比較し, 適切な材料を提案した報告 はない。このようなスタディを施行するには実験環境 に左右されにくく，再現性の高いシステムが必要であ る。そのために, 本研究では一般に比較的安価で入手 しやすい材料やシステムを使用して, 複数の種類の拡 散強調画像用ファントムを作製し, 温度変化や画質の 観点から特性を確認して, ファントムスタディとして 最適な材料を提案した。

\section{1. 方 法}

\section{1-1 使用機器と対象}

使用装置は 1.5 T の Brivo MR355 (GE Healthcare, Milwaukee, WI, USA) およびアレイコイルのコイルエ レメントごとの感度の影響を排除するために頭部用ク ワドラチャーコイルを使用し，ファントムとして 1 $\mathrm{wt} \%$ アガロース (HyAgarose ${ }^{\mathrm{TM}} \mathrm{LE}$ ，スカイサイエン ス：神戸)と $0.9 \mathrm{wt} \% \mathrm{NaCl}$ を対象材料に加えて作成し た。ファントムは MRI 検查室内の温度 $\left(22.7^{\circ} \mathrm{C}\right)$ で共 通条件として ADCが1に近似するように，ポリエチ レングリコール $20 \mathrm{wt} \%$ (polyethylene glycol: PEG, $\mathrm{T}_{1}$ 值, $1030 \mathrm{~ms}$; $\mathrm{T}_{2}$ 值, $250 \mathrm{~ms}$, 林純薬工業, 大阪), デ キストリン $30 \mathrm{wt} \%$ (dextrin: DEX, $\mathrm{T}_{1}$ 值, $662 \mathrm{~ms}$; $\mathrm{T}_{2}$ 值, $39 \mathrm{~ms}$, 林純薬工業, 大阪), およびスクロース 30 wt\% (sucrose: SC, $\mathrm{T}_{1}$ 值, $914 \mathrm{~ms}$; $\mathrm{T}_{2}$ 値, $57 \mathrm{~ms}$, 和 光純薬, 大阪)をそれぞれ使用し, ポリプロピレン容器 (40×115×40 mm：幅×高さ×奥行)に同封して作製した (以下, エレメントと称する). MRI 検查室内 $\left(22.7^{\circ} \mathrm{C}\right)$ でADCを測定した結果, PEG が $1.00 \times 10^{-3} \mathrm{~mm}^{2} / \mathrm{s}$, DEX が $1.12 \times 10^{-3} \mathrm{~mm}^{2} / \mathrm{s}, \mathrm{SC}$ が $1.11 \times 10^{-3} \mathrm{~mm}^{2} / \mathrm{s}$ で あった，各ファントムの組成表を Table に示す。こ れらの各エレメントを更に別のポリプロピレン容器 (90×140×140 mm：幅×高さ×奥行)に入れ，周囲を 1 wt \% アガロースで固定してファントムとした(ファン トムA) (Fig. 1a)。また, 拡散強調画像の撮像に用い た材料を封入したポリプロピレン容器内の温度は, 外
部からの直接測定は不可能なため, もう一体温度測定 用として，別途，ファントムを作製した(ファントム B). ファントム B は, ファントム A と同型の容器に $1 \mathrm{wt} \%$ アガロースをファントム A と同様の高さまで 充填し, ファントム中央の温度を測定できるように, 中央にて上下二段に分割できるような構造とした (Fig. 1b).

作製したファントム A を以下の条件にて撮像した. 周波数選択脂肪抑制法を併用したエコープラナー法を 用いて, 繰り返し時間 (repetition time: TR) は 5000 ms, エコー時間 (echo time: TE) は 89.0-89.3 ms, マト リクスは $128 \times 128$ (周波数エンコード数 $\times$ 位相エンコー ド数), 撮像領域は $256 \times 256 \mathrm{~mm}$ (周波数エンコード方 向×位相エンコード方向), スライス厚は $5.0 \mathrm{~mm}$, ス ライス数は 1 枚, 加算回数は 1 回, 受信バンド幅は土 $15.63 \mathrm{kHz}, \quad \mathrm{b}$ 值は 0 および $1000 \mathrm{~s} / \mathrm{mm}^{2}$, 撮像時間は 25 秒でファントム A 中央を水平断面にて撮像した。 なお，スキャン前後で温度が変化することを避けるた めにファントムの撮像は 5 回とし, 5 回の測定の平均 值を各温度の測定值とした。測定温度は, 撮像の直前 と 5 回撮像した直後の 2 回行った. ファントムAお よびB の温度調節には冷温庫 (Rockpals RP10 L : パー フェクトレード, 東京), 温度測定には非接触型の赤外 線温度計 (Aidbucks AD6530B)を用いた。画像解析に は ImageJ v.1.52r (National Institute of Health, Bethesda, MD, USA), データ処理には Microsoft Excel(Microsoft, Redmond, WA, USA), 統計処理には EZR v.1.37 ${ }^{10)}$ を用いた。

\section{1-2 温度変化における ADC の測定}

ファントムの ADCにおける依存特性を調査するた めに, ファントム A jよび $\mathrm{B}$ を冷温庫で温度を変化 させて撮像し, ファントム $\mathrm{A}$ の各エレメントの $\mathrm{ADC}$ を測定した。体温変化による影響をファントムでシ ミュレーションするために, まず MRI 検查室温 $\left(22.7^{\circ} \mathrm{C}\right)$ から $5^{\circ} \mathrm{C}$ まで $5^{\circ} \mathrm{C}$ 間隔で低下させ, 一度 MRI 検査室温に戻してから $50^{\circ} \mathrm{C}$ まで $5^{\circ} \mathrm{C}$ 間隔で上昇させ た，その際，ファントム全体を同等の温度にするため に冷温庫内で 10 時間以上静置した ${ }^{11)}$ 。なお，静置 10 


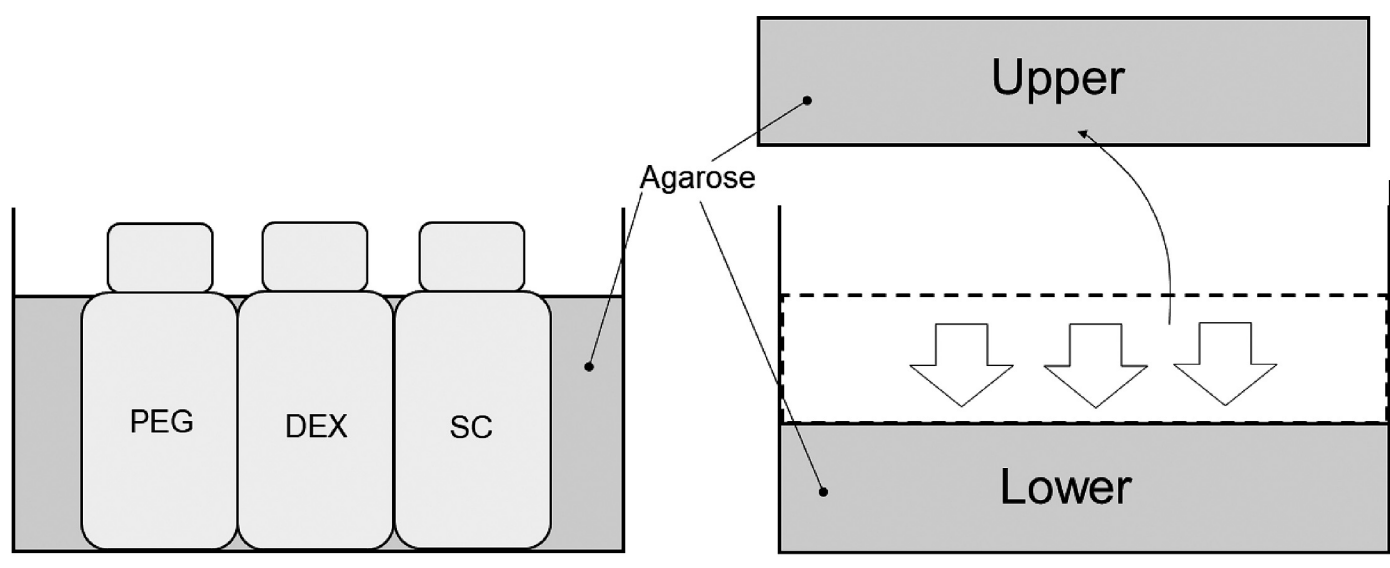

Phantom A

Phantom B

Measurement point

Fig. 1 Phantom configuration.

(a) Enclose three types of elements in a container and fix with agarose.

(b) Separate the two-layer phantom for temperature measurement in terms of region of interest for measurement. When measuring, remove the upper part and measure the temperature at the measurement of the phantom installation point.

DEX: dextrin, PEG: polyethylene glycol, SC: sucrose

時間後にファントム中央と表面が同じ温度を保ってい ることは事前に確認した。実際のファントム内温度測 定にはファントム B の上段を取り除き，下段表面(す なわちエレメント中央)の温度を測定し，それをファ ントム Aの撮像断面の温度として使用した。得られ たb0 およびb1000 画像のそれぞれのエレメント断面 の中心部分に関心領域 (region of interest: ROI, 平均 $779 \mathrm{~mm}^{2}$ )を設定した(Fig. 2). ROI 内の信号強度を 測定し，以下の式を用いて ADC を算出した。

$$
\mathrm{ADC}=-\operatorname{In}(S 1000 / S 0) /(b 1000-b 0)
$$

$\mathrm{S} 0$ は b0 s/mm² の信号值, $\mathrm{S} 1000$ は $\mathrm{b} 1000 \mathrm{~s} / \mathrm{mm}^{2}$ の 信号值を表す。また，それぞれの試料の実測温度間で の ADC をもとに線形近似を行い, 傾きを変化率とし た. $1^{\circ} \mathrm{C}$ 当たりの変化率に対するそれぞれの試料の有 意差を Friedman 検定㧍よび, Steel-Dwass 多重比較 検定にて求めた $(P=0.05)$.

\section{1-3 温度変化における信号一雑音比の測定}

1-2 で得られた b1000 s/mm² の画像に扔けるファン トムの画質の変化を確認するために, 信号一雑音比 (signal-to-noise ratio: SNR) map を作成した。また, SNR の変化の原因を探るためにノイズ画像を作成し, 標準偏差の算術平均值を測定した。なお， ROI の設定

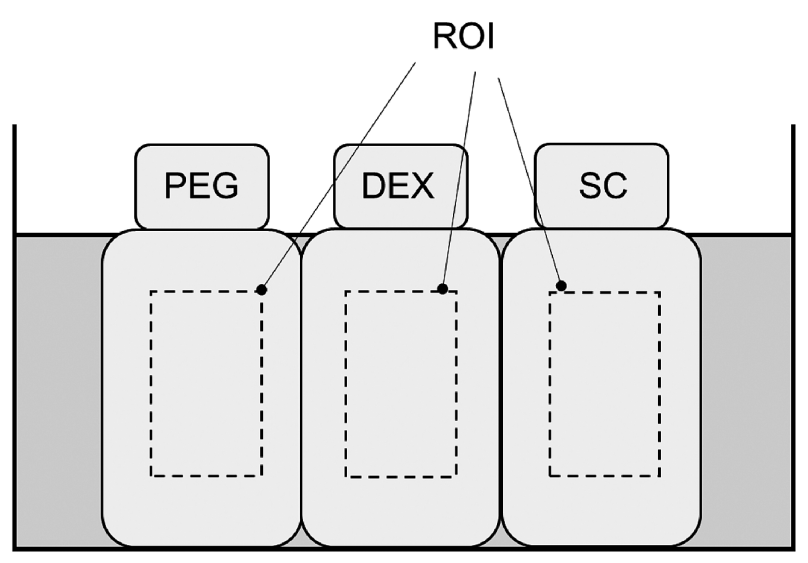

\section{Phantom A}

Fig. 2 Phantom centric region of interest measured signal strength.

は1-2 と同様とし，画像解析には日本放射線技術学会 の画像部会から提供されている ImageJ の Plugin を 使用した。

\section{2. 結 果}

2-1 温度変化における ADC の測定

ファントムの温度と ADC の関係を Fig. 3 に示す.

ファントムの温度は必ずしも $5^{\circ} \mathrm{C}$ 間隔にならなかった 


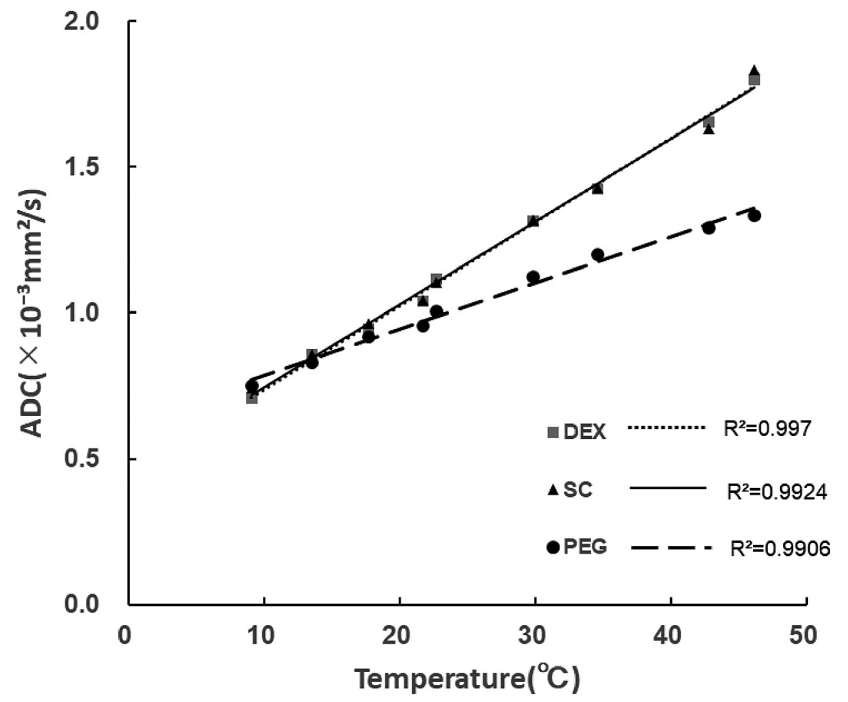

Fig. 3 Measurement for the relationship between phantom and temperature. DEX and SC have almost the same graphs. However, PEG presented a gentle slope in contrast to other phantoms.

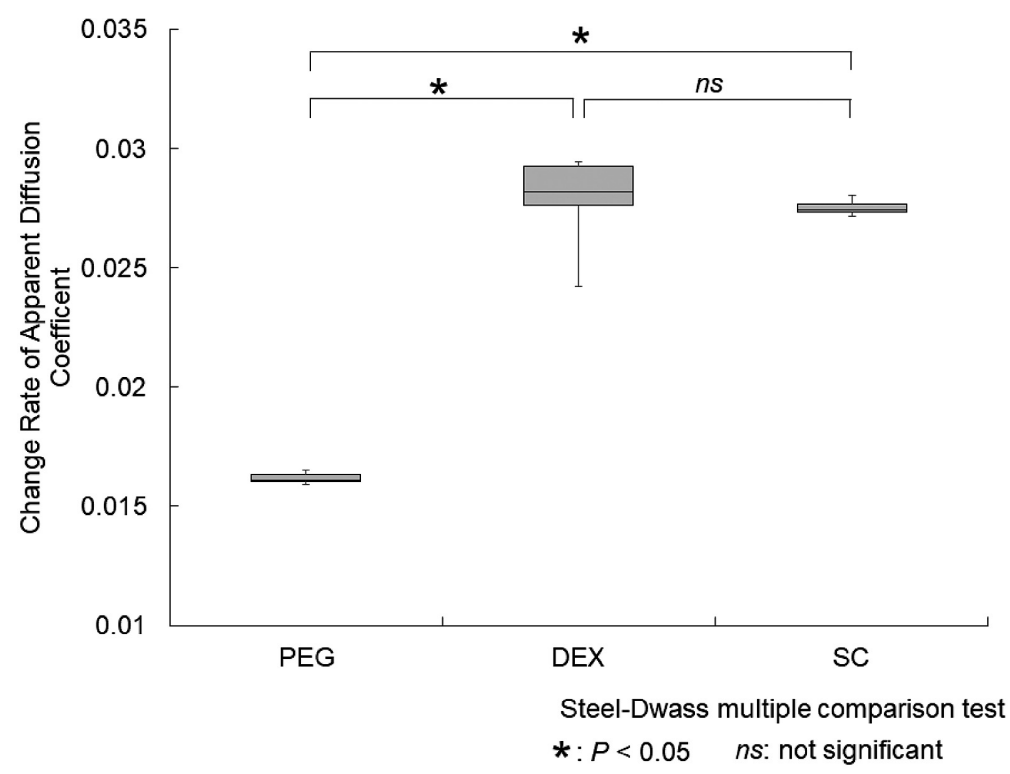

Fig. 4 Change rate of apparent diffusion coefficient. There was a significant difference $(P<0.05)$ except between DEX and SC $(P=0.48)$ according to the Steel-Dwass multiple comparison test.

が，ADC は温度の上昇とともに大きくなった，DEX とSC はほぼ重なったグラフとなったが，PEGは，他 の二つのファントムと比較して, 緩やかな傾きを呈し た. $\mathrm{ADC}$ の変化率は, PEGでは $1.62 \% /{ }^{\circ} \mathrm{C}, \mathrm{DEX}$ で は $2.78 \% /{ }^{\circ} \mathrm{C}$ ，および $\mathrm{SC}$ では $2.75 \% /{ }^{\circ} \mathrm{C}$ であった。 ま た，変化率に対するそれぞれの材料について統計解析 を行った結果, MRI 検査室温における中央值および四 分位範囲は, PEGでは 89.4 および $6.28, \mathrm{DEX}$ では

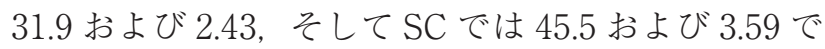

あった. Friedman 検定では有意差あり $(P<0.01)$, Steel-Dwass 多重比較検定では DEX と SC 間 $(P=$ 0.48) 以外は有意差があった $(P<0.05)$ (Fig. 4).

\section{2-2 温度変化における信号一雑音比の測定}

実際に撮像したファントムの画像を Fig. 5 に示す. b1000 s/mm² の画像の SNR の測定結果を Fig. 6aに 示す. PEGが最も高く, 次いで $\mathrm{SC}$, 最も低いのは DEX であったＰ PEG と SC は温度が高くなるに従っ 


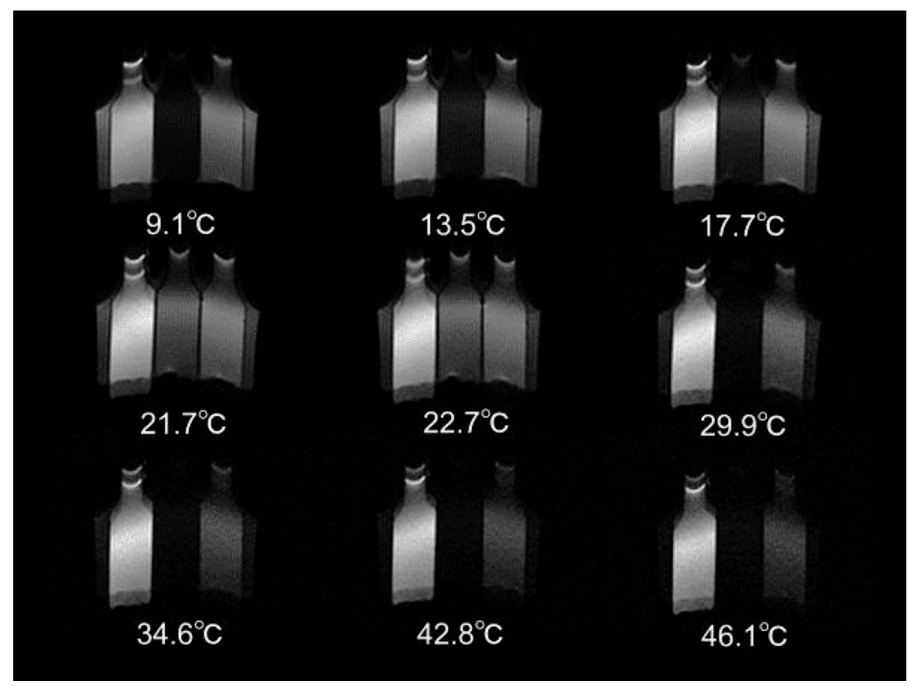

Fig. 5 Actually measured, b1000 s/ $\mathrm{mm}^{2}$ image of the phantom at each temperature.

PEG on the left side was the highest value. DEX could hardly obtain a signal except in the room temperature vicinity.
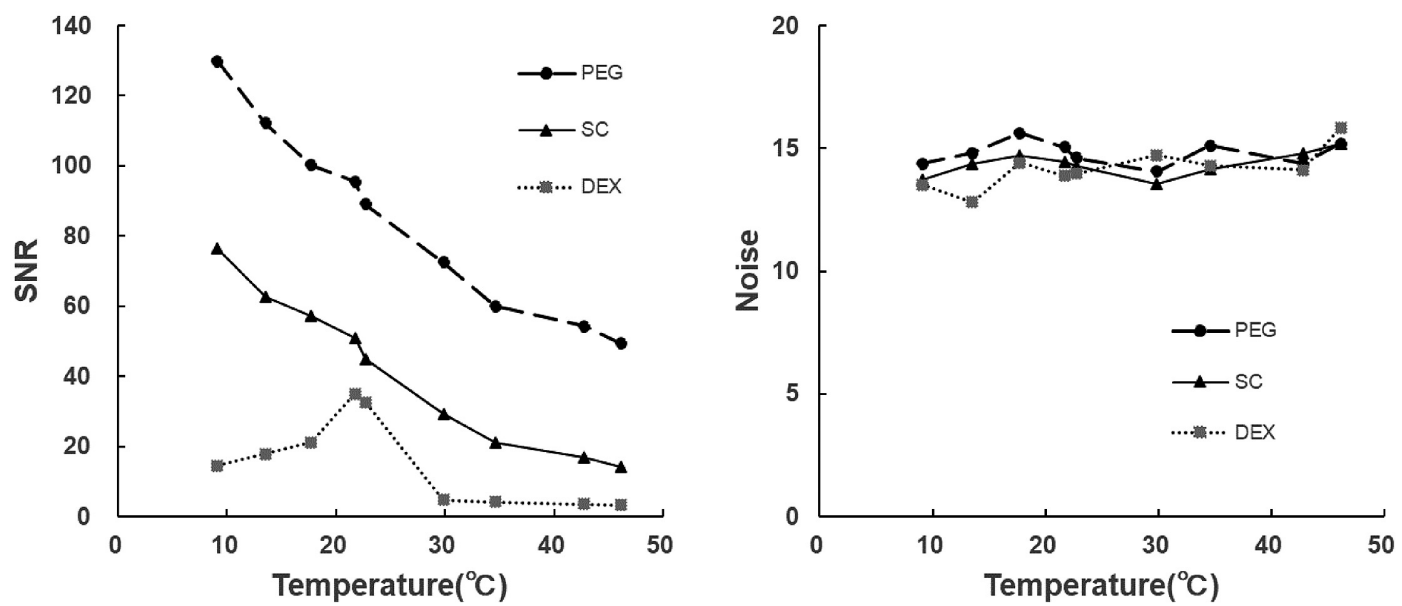

Fig. 6 Measurement of the signal-to-noise ratio (SNR) (a) and noise value (b) in the b1000 images.

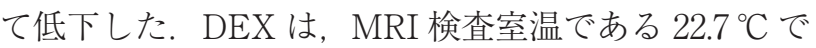
最も高い值を示したが，すべての温度で他のエレメン トよりも低い值を示した.ノイズの測定結果を Fig. $6 \mathrm{~b}$ に示す。温度変化によるノイズへの顕著な影響は みられなかった。

\section{3. 考 察}

\section{3-1 温度変化における ADC の測定}

単位時間当たりのプロトンの拡散面積で表される拡 散係数は，温度上昇によって分子のブラウン運動が激 しくなるために増加することが知られており ${ }^{12)}$, した がって ADC は増大したと考える。今回の実験系の
PEGのエレメントは他のものよりも温度上昇による ブラウン運動への影響は少ないと考える。

ファントム実験に適した材料を考えるうえで, Stokes-Einstein の式(2)を参考にすると，他のファク 夕を共通項とした場合，拡散係数と絶対温度の関係が 比例することを意味する。

$$
D=\frac{k T}{6 \pi \eta r}
$$

$\left[D\right.$ : 拡散係数 $\left(\mathrm{m}^{2} / \mathrm{s}\right), k$ : ボルツマン定数 $(1.381 \times$ $\left.10-{ }^{23} \mathrm{~J} / \mathrm{K}\right), \quad T$ : 絶対温度 $(\mathrm{K}), \quad \eta$ : 粘度 $(\mathrm{kg} / \mathrm{sm}), r$ : 拡散係数の半径] 
今回使用した MRI 検查室温度 $\left(22.7^{\circ} \mathrm{C}\right)$ における

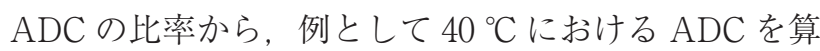
出すると $(40+273.16) /(22.7+273.16)(\mathrm{K})$ となり, 各 MRI 検査室温度 $\left(22.7^{\circ} \mathrm{C}\right)$ における ADC を乗じると PEG は 1.06, DEX は 1.19, SC は 1.18 と算出された. 今回の測定值から $40^{\circ} \mathrm{C}$ における ADC を算出すると,

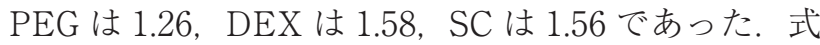
(2) で求められる值を真值とすると, 測定值との相対 誤差は PEGは 0.19, DEX は 0.33, SC は 0.32 であっ た.よって，真值に近い変化を示すものはPEGで あった。すなわち, PEGが真值に近いファントムとし て使用できると考える。

ファントムの温度設定について, 非接触赤外線温度 計は瞬時に測定が可能だが, $\pm 2{ }^{\circ} \mathrm{C}$ の測定誤差をもつ. 冷温庫や非接触型赤外線温度計の精度が影響して温度 が一致しないことによる影響が考えられる，温度管理 の精度に関して, 同一形状で同じ温度管理システムを 使用しているため直接測定と同様であると考えるが, 比較はしていない。しかし，同一環境下で簡便に使用 できる機材としては安価で使いやすいファントムであ ると考える，ADCを完全に統一することは困難で あったが，エレメントの傾向を評価することができた と考える。

\section{3-2 b1000s $/ \mathrm{mm}^{2}$ の画像の SNR とノイズ測定}

今回の実験系において，ファントム位置やスライス の設定は毎回同一としているにもかかわらず TEが変 化した。これは TEの設定を最短としていることによ り, 毎スキャンの微妙な位置の変化により TEが延長 したと考えられる。TEを固定できなかったことにつ いて, SNRにどのような影響を与えているかは検証で きていない. しかしながら，ADCの值はTEによら ず一定で，変化しないという報告もあり7)，今回の実 験系におけるADCの結果には影響していないと考え る。一方 SNR には影響している可能性があるが，本 実験の目的を鑑みた傾向は確認できたと考える。

温度が高くなるに従って SNR が低下するグラフが 得られた。ファントムのもつ熱がコイルに伝播するこ とによる熱雑音の増大によって，ノイズ成分が増加し SNR の低下につながると考えていたが, 三つのエレメ ントのいずれも温度変化によるノイズ上昇への影響は みられなかった。拡散画像の信号強度 SDWI は式(3) で表され ${ }^{13)}, \mathrm{T}_{2}$ の影響が関与する.

$S_{D W I}=C_{e x p}\left(-T E / T_{2}\right) \exp (-b D)$

$[C$ : 比例定数, $D$ : 拡散係数 $]$
$\mathrm{T}_{2}$ は磁気双極子モーメントが周囲の局所磁場の変 化によりプロトンの位相分散に影響を与え, 横磁化が 減衰していく過程の時定数である。局所磁場は周囲の 温度とそれに伴う分子のブラウン運動によって変化す る。よって, b1000 s/ $\mathrm{mm}^{2}$ の画像の信号強度は温度に よって低下したと考える。

結果より Stokes-Einstein の式に近く, SNR が最も 高いものはPEG であることが明確になった．SNR の 上昇は画質をも向上させ，コントラスト・雑音比も向 上させる. PEG はファントムによるシミュレーショ ンを行う際，信号評価をするうえで，他のファントム よりも優れていると考える.

DEX は他のファントムと比べて低い SNR を示した が, 他のファントムと異なる点として, MRI 検査室温 より温度が低い場合に SNRの低下がみられる，MRI 検査室温付近より温度が高い場合は PEG, SC と同様 にSNR の低下の傾向を示すが, 室温より低い温度で はSNR が低下している。同一環境下で DEX のみ SNR が低下しているので，DEX 自体に問題があると 考えられる。 DEX は，でんぷんの加水分解の程度を 表す指標として dextrose equivalent (DE) と呼ばれる 指標が利用されており, 特にDEが低いものは溶解性 の低さ, 低温で保存することによる濁りの発生や沈殿 の析出などが問題となる ${ }^{14)}$ 。このことから，低温に設 定した際の何等かの変性による信号強度の低下が考え られるが，今回の実験系では詳細は明らかにはできな かった，設定温度を変化させる際に低温から選択した ことにより，高温選択時には既に変性していたため, 高温の信号強度にも影響した可能性がある。DEX は SNRが低かったものの，ADC は真值と極端な差があ るわけではない. SC も同様であり, 安価で使用しや すいことはファントムとして選択の余地はあると考え る。しかしながら, 本研究は今回の実験系において各 エレメントの特性を明らかにすることであり, 最も相 応しいファントムとしてPEG という結果が得られた。

この研究にはほかにいくつかの limitation がある. 本研究では ADC を変化させた場合や, $b$ 值を変化さ せた場合，また磁場強度を変化させた場合の影響につ いては検討していない，また，液体ファントムでは温 度変化により対流が起きて信号測定に影響するため, 今回はアガロースで固定したが, 固定物質が異なる場 合は影響する可能性がある，更に，本実験系では室温 からの変化を行ったが, 高温から行った場合の検討は 同一ファントムの経時変化などを考えて施行しなかっ た，以上により，別途更に検討する必要があると考 える。 


\section{4. 結 語}

三つのファントムを作製し, 温度変化における依存 特性を ADC および SNR について評価した。温度変 化に対する ADCをStokes-Einsteinの式を参考にし て真值と測定值の差について比較した結果, PEGが最 も近い值を示した.SNRに関しても高い值を示して いることから, PEGを最適なファントムとして提案で きる。

\section{謝 辞}

本研究に際しご指導いただいた群馬県立県民健康科 学大学の小倉明夫教授に感謝申し上げます.

\section{利益相反}

執筆者全員において開示すべき利益相反はない.

\section{参考文献}

1）表利知幸, 星野貴志, 丸山喜仁, 他. 早期脳梗塞診断にお ける Diffusion MRI の役割. 日放技学誌 2006; 62(10): 1422-1427.

2) 出口一郎, 傳法倫久, 内野 晃, 他. 脳梗塞急性期におけ る拡散強調 MRI の有用性について。脳卒中 2011; 33(5): 473-479.

3) 高原太郎, 今井 裕. 全身の拡散強調画像 (DWIBS)につ いて. 日磁医誌 2005; 25(4): 247-254.

4）藤原康博. 脳血管障害の画像診断に役立つ MR 画像情報 と撮像プロトコールの組み立て方. 日放技学誌 2013; 69 (10): 1187-1194.

5) Chenevert TL, Galbán CJ, Ivancevic MK, et al. Diffusion coefficient measurement using a temperature-controlled fluid for quality control in multicenter studies. J Magn Reson Imaging 2011; 34(4): 983-987.

6) 高橋雅彦, 橋本真衣子, 上原真澄。拡散強調画像用急性期 微小脳梗塞ファントムの作製. 日放技学誌 2018; 74(6): 531-538.

7）田村隆行, 笛吹修治, 秋山實利。ゼラチンとスクロースを 用いた拡散強調画像用ファントムの検討. 日放技学誌 2009; 65(11): 1485-1493.

8) Takatsu Y, Sagawa H, Nakamura M, et al. Novel distortion correction method for diffusion-weighted imaging based on non-rigid image registration between low $\mathrm{b}$ value image and anatomical image. Magn Reson Imaging 2019; 57: 277-284.

9) Gatidis S, Schmidt H, Martirosian P, et al. Development of an MRI phantom for diffusion-weighted imaging with independent adjustment of apparent diffusion coefficient values and T2 relaxation times. Magn Reson Med 2014; 72(2): 459-463.

10) Kanda $Y$. Investigation of the freely available easy-to-use software 'EZR' for medical statistics. Bone Marrow Transplant 2013: 48, 452-458.

11）高津安男, 木村哲哉, 佐原朋広。ファントムスタデイにお ける MRI 信号強度の温度依存性. 日磁医誌 2011; 31(1): $32-40$.

12) Quesson B, de Zwart JA, Moonen CT. Magnetic resonance temperature imaging for guidance of thermotherapy. J Magn Reson Imaging 2000; 12(4): 525-533.

13）青木茂樹，他．生体と拡散現象。これでわかる拡散 MRI 第 3 版。学研メディカル秀潤社, 東京, 2013: 17.

14）農畜産業振興機構。難消化性デキストリンの特性と用途. https://www.alic.go.jp/joho-d/joho08 000547.html(アクセス 日 2020.3.30)。 